\title{
Exploring the Application of Computer-Assisted English Learning in a Chinese Mainland Context: Based on Students' Attitudes and Behaviours
}

\author{
Jinjin Lu ${ }^{1}$, Paul Throssell ${ }^{1} \&$ Han Jiang ${ }^{2}$ \\ ${ }^{1}$ Faculty of Education, University of Tasmania, Australia \\ ${ }^{2}$ Faculty of Education, University of Wollongong, Australia \\ Correspondence: Jinjin Lu, Faculty of Education, University of Tasmania, Australia. Tel: 61-042-098-3573. \\ E-mail: jlu14@utas.edu.au
}



\begin{abstract}
Computer-assisted language learning (CALL) has played an important role in language curriculums for Chinese schools and university over two decades; however, few researchers rare focused on this applicable tool from students' views. Based on theories of human agency, it is essential to know people' attitudes and acceptance of the information technology (Rogers, 1983). Hence, this paper explores university students' attitudes on the widespread teaching and learning approaches utilising computer-assisted language learning in the subject university in mainland China. Data was collected by using both quantitative and qualitative methods. Current computer-related behaviours were investigated by using a questionnaire; while their attitudes towards the application of CALL in universities was further explored by adopting a semi-structured interview. On the one hand, the results of the survey present that students do not use computers to assist their English learning. However, on the other hand, the interviews indicate that students hold a positive attitude on applying CALL in English classes if efficient guidance is available. It suggests that more accompanied trainings and workshops would be provided in Chinese mainland universities for university students to improve their capacities of applying CALL to their English learning.
\end{abstract}

Keywords: information technology (IT), computer-assisted language learning (CALL), attitude and behaviour

\section{Introduction}

Emails, the World Wide Web and various digital technologies have been widely used over the past two decades. In addition, there are more electronic devices and e-related subjects involved in our daily life, for example, e-government, e-business, and e-learning. Particularly, e-related educational techniques and devices are popular among schools and teachers. Although CALL is one form of those applicable technologies, especially in the field of language education, it is still a sector of "Cinderella" education in mainland China (Furstenberg, 1997). Some researchers believed this IT tool is a panacea for language learning and teaching and is a counter-measure to serious concerns in language learning and teaching (Braul, 2006; Cubillos, 1998; S. C. Yang \& Chen, 2007). However, Markee(1997) argued that program developers ignored the role of innovation participants in the early 1980s, which caused the lack of computer utilization in education. Warschauer(2002) claims that it plays an important role in human capacity and motivation for technological innovations.

\section{Literature Review}

A large quantity of previous research results regarding CALL have indicated that students, teachers and school principals held a positive attitude on this remedial tool applied in language teaching and learning (Fan, 2011; Stockwell \& Harrington, 2003; Wang, 2004; P. J. Yang, 1998). However, few researchers explored Chinese students' behaviors and attitudes in Chinese territory educational institutions. Thus, it is believed that investigating participants' views on the application of CALL based on the human element is essential, and can benefit future language learning and teaching in China.

\subsection{Human Agency}

Human agency is a broad term to address human intervention issues that influences technology use. However, it 
is often focused uponcomputer-related attitudes (Seyed \& Farimah, 2013). Previous research mentioned above did not show the human element as an important role which has been involved in IT related- projects. Researchers, such as Yang and Tsai (2008) argued that a major problem in the development of IT projects is the limited understanding of users' characteristics. Similarly, Ma, Andersson, and Streith(2005) also argued that the wide use of computers cannot guarantee the popularity and effective use of CALL. They also declared that there is need to know where computers are allocated. Their arguments were supported by Kern (2006), who claimed that the way to use specific technologies in the different contexts is more vital than whether it is effectively used or not. Kessler (2007) and Jung (2005) proposed some issues need attention and highlighted that attitudes towards computer technology. Although these researches were conducted in western countries, they still shed lights on matters on human agency in a variety of contextual background. Consequently, humans' attitudes on computer technology cannot be ignored.

\subsection{CALL Attitudes}

Users' attitudes have been become a popular research topic in CALL studies in the $21^{\text {st }}$ century. Ma, et al (2005)found that attitudes could have a mediating effect when using technology. The psychologist Rogers (1983) puts forward the idea that users' attitudes play an important role in the widespread of innovations and the attitudes to use these innovations will affect actual use. Thus, it is believed that attitudes towards computing technology will affect learning with computers since we see IT as an ongoing area of innovation (Davis, 1989; Fisher, 1993). An influx of research has demonstrated that the value of attitudes and in particular users' positive attitudes towards the new technology is a key element to develop transformation in education (Albirini, 2006; Cox, Preston, \& Cox, 1999; Liaw, 2002; Ma, et al., 2005; Yuen \& Ma, 2002).

Although the importance of the role of attitudes towards technology integration has been widely reviewed, yet, an investigation of Chinese users' attitudes is essential in understandings the influence of innovation in the application of CALL in China. However, according to Davis (1989) and Ma (2005), when considering users' attitudes towards technologies, other influential factors cannot be ignored, such as confidence in the use of IT, personal access to IT, positive attitudes towards to educational change, technical support, quality training, and the cultural relevance of IT. All these factors can influence users' attitudes towards IT to some extent. Fewresearch studies have touched on Chinese mainland users' attitudes to this innovation. As a basis to understand CALL in mainland China, it is necessary to describe recent the development of the background context.

At the beginning of 2004, the Ministry of Education of China initiated the first round of a nationwide research-oriented reform in English language teaching in China by selecting four multimedia web-based English course textbooks published by four academic presses in Beijing and Shanghai to be piloted in 180 colleges and universities for one academic year. Within these 180 colleges and universities, they called this multimedia web-based English courseas 'College-English' course. These 180 institutions are required to implement computer-assisted multimedia-supported online courses into their 'College English' curriculum, to carry out empirical studies on their effectiveness, and to publish their findings in academic journals.

As a result of a series of top-down reforms in language teaching, the last decade has witnessed an increasing interest in this topic among Chinese researchers. For example, a subject keyword search with 'college English' and 'web' or 'multimedia' in Chinese academic journals (CNKI) database, the results show that 114 hits between 1995-2003, while the same search in the years 2003-2005 results in 126 hits. However, the numbers of the publications were over 1000 at the end of 2010. Therefore, it can be seen that the application of CALL has aroused Chinese researchers' interest but within the CALL usage has tended to focus on studies related to the initial governmental policy decisions instead of human agency.

\section{The study}

\subsection{Research Questions}

Three research questions were formulated in this study to envisage the application of CALL attitudes of the university students in the mainland of China.

- What is the behavior of Chinese university students using CALL?

- What is the attitude of Chinese university students towards CALL?

- Is there any relation with the behaviors and the attitudes?

\subsection{Methodology}

Mixed methods were utilised through both quantitative and qualitative methods to collect and analyse data. It is 
believed that these two methods can be used separately in different phrases in a study (Tashakkori \& Teddlie, 1998). Using both quantitative and qualitative methods in a research can be very important and beneficial(Johnson \& Onwuegbuzie, 2004). First of all, it can enable the researcher to have a broaderperspective on data collection and analysis. Also, during this process, the researcher could gain deeper insights into the views of the participants within the research area. Therefore, the findings of the study are believed to be more likely to have utilizedthe strengths of mixed methods and offset the weakness of using only one of them(Johnson \& Turner, 2002). It is believed that the overall strength of this research is potentially greater than the studies based on only one method (Creswell, 2009).

\subsection{Participants}

347 university students from two Chinese universities participated in the survey in the first phrase and 20 of them joined in the semi-structured interview in the second phrase. One university is located in the middle part of mainland China, which has a high reputation for education quality and academic records. The other one is in the southern part of China, which lies close to Hong Kong and Macau. These two universities were among the 180 universities, which was in the first-round reform to adopt CALL in their English teaching and learning at early stage. Thus, they were considered to be representative of many of the universities participated in CALL adoption.

\subsection{Instrument Design}

In the first phrase, the questionnaire was designed to examine students' behaviors in their usageof CALL.It adopted a five-Likert Scale (Likert, 1932). In the survey, 24 questions addressed different items regarding the use of CALL. Students were asked to choose the most appropriate answer according to their actual use of CALL in their English class and also out of class. The responses range from never (1), to seldom (2), to sometimes (3), to often (4), and to very often (5). Higher scores indicated that students would like adopting CALL to their English learning process. The semi-structured interview was conducted after the survey in the second phrase, and included 10 questions. These 10 questions were believed to further explore students' views towards their use of CALL in learning as a supplement to the questionnaire.Both the questionnaire and interview questions were translated into the Mandarin language as Brown (2001) suggested that questions should be designed at an appropriate level in order to minimize measurement error, for example, to provide questions that are mostly in the first language of respondents.

\subsection{Pilot Study}

Two stages were enacted to ensure the validity and to students' of translations suitability of the two research tools. The researcher invited two TESOL (Teaching English as Other Languages) academic staff and two students majoring in English literacy to read the English version of the question items as well as the Chinese versions so that the accuracy of the questions could be approved. After this initial evaluation process, five university students piloted the revised versions of the questionnaire and interview questions.

\subsection{Data Analysis}

The Statistics Software SPSS 20.0 was used to analyse the quantitative data. Descriptive statistics and non-parametric, including Kruskal-Wallis Test and Mann-Whitney U Test, were used to describe the answers to the questionnaire. However, for the qualitative data, NVivo version 10 was adopted to provide students' attitudes with a 'data-grounded' method (Bazeley, 2010). This method allows the researcher to keep a close eye to phenomenon without any assumptions at the very beginning and then to compare incidents constantly to build higher-level themes. Afterwards, core categories emerged from this process by comparing and relocating within these textual data.

\section{Results of Quantitative Data}

The first part of the questionnaire has five items regarding participants' background information, such as gender, academic facility, and the nationality. The details of the participants' demographical information are presented below: 




Figure 1. Number of male and female students



Figure 2. Number of students' nationalities

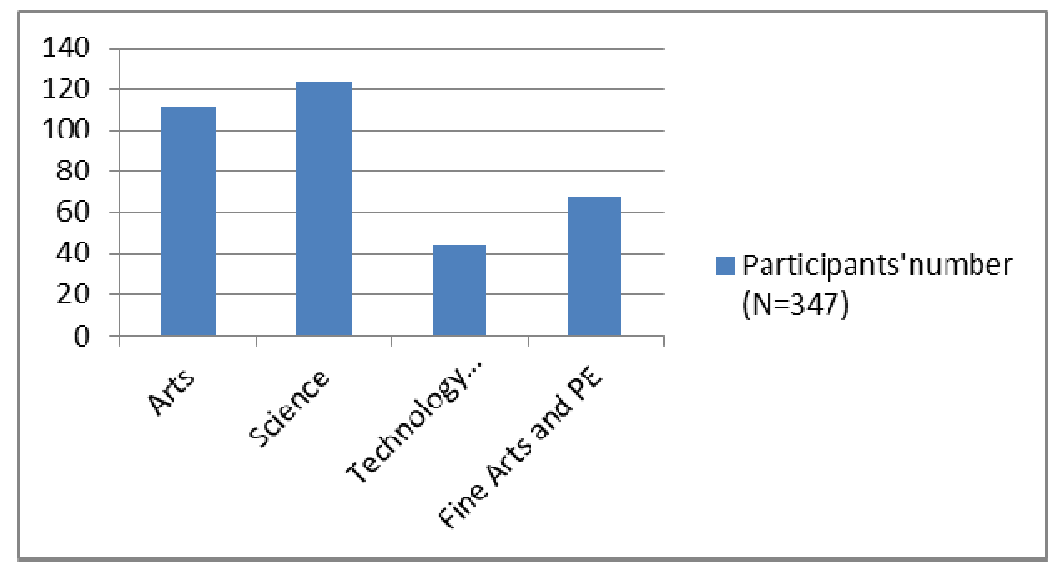

Figure 3. Number of students' in four disciplines 


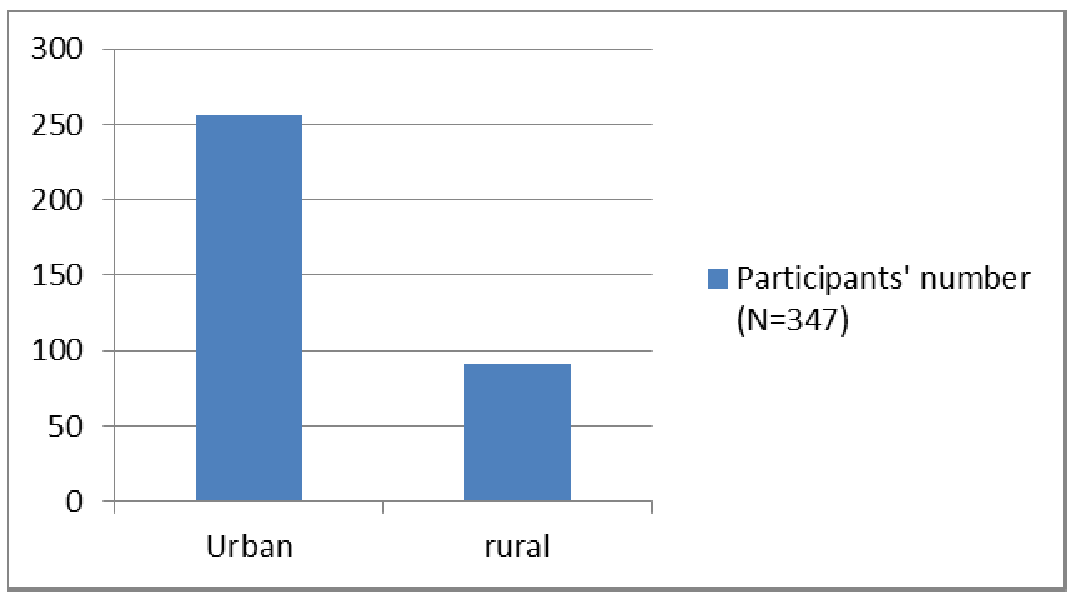

Figure 4. Number of the participants from urban areas and rural areas

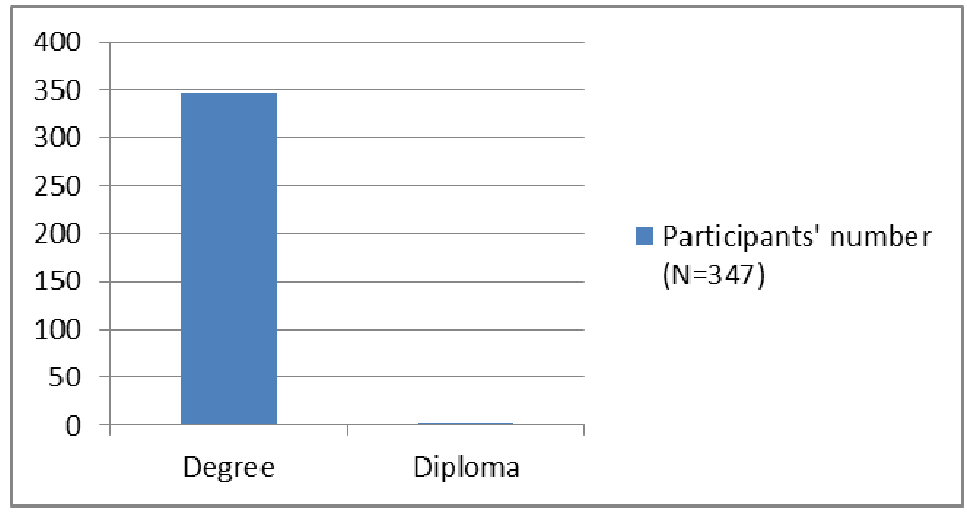

Figure 5. Number of the participants' courses

The background information of the 347 participants is shown in the tables above, including 163 male and 184 female students, 326 Han students and 21 minority students. Within four academic disciplines, more than half of the total number of students are from Arts $(\mathrm{N}=112)$ and Science $(\mathrm{N}-123)$, followed by Fine Arts \& PE education $(\mathrm{N}=68)$ and Technology Engineering $(\mathrm{N}=44)$. Among these 347 participants, 245 of them finished their secondary education in urban areas, which outweighed the number in rural areas $(\mathrm{N}=91)$. Interestingly, there was only one student who undertook diploma study joined in this study.

The second part of the questionnaire aim was to investigate students' behavior of using CALL in English classrooms and out of classrooms. The 24 question items were designed to address research questions, including using the computer as a media to finish assignments, to communicate with others, and to take other English activities. The descriptive analysis was firstly explored on these 24 question items to obtain general information of the participants' responses. 
Table 1. Descriptive analysis

\begin{tabular}{|c|c|c|c|c|c|}
\hline Questions & Mean & $\begin{array}{l}\text { Media } \\
\mathbf{n}\end{array}$ & Mode & $\begin{array}{l}\text { Std. } \\
\text { Deviation }\end{array}$ & Variance \\
\hline No.1 & 2.207 & 2.000 & 2.0 & .7773 & .604 \\
\hline No 2 & 2.784 & 3.000 & 3.0 & .8202 & .673 \\
\hline No 3 & 2.784 & 1.000 & 1.0 & .6669 & .445 \\
\hline No 4 & 1.859 & 2.000 & 2.0 & .8603 & .740 \\
\hline No 5 & 1.349 & 1.000 & 1.0 & .7269 & .528 \\
\hline No 6 & 1.637 & 1.000 & 1.0 & .8436 & .712 \\
\hline No 7 & 2.037 & 2.000 & 2.0 & .8372 & .701 \\
\hline No 8 & 1.988 & 2.000 & 2.0 & .7937 & .630 \\
\hline No 9 & 3.308 & 3.000 & 3.0 & 1.0590 & 1.121 \\
\hline No 10 & 1.951 & 2.000 & 1.0 & .9769 & .954 \\
\hline No 11 & 1.395 & 1.000 & 1.0 & .7191 & .517 \\
\hline No 12 & 1.254 & 1.000 & 1.0 & .6216 & .386 \\
\hline No 13 & 2.089 & 2.000 & 2.0 & .8436 & .712 \\
\hline No 14 & 1.951 & 2.000 & 1.0 & .9437 & .891 \\
\hline No 15 & 1.323 & 1.000 & 1.0 & .7485 & .560 \\
\hline No 16 & 2.585 & 3.000 & 2.0 & .9222 & .850 \\
\hline No 17 & 1.893 & 2.000 & 1.0 & 1.0979 & 1.205 \\
\hline No 18 & 1.669 & 1.000 & 1.0 & .8583 & .737 \\
\hline No 19 & 1.986 & 2.000 & 2.0 & .8345 & .696 \\
\hline No 20 & 2.012 & 2.000 & 2.0 & .8963 & .803 \\
\hline No 21 & 1.761 & 2.000 & 1.0 & .9173 & .841 \\
\hline No 22 & 1.530 & 1.000 & 1.0 & .7141 & .510 \\
\hline No 23 & 3.628 & 4.000 & 4.0 & .9899 & .980 \\
\hline No 24 & 1.813 & 2.000 & 1.0 & .9896 & .979 \\
\hline
\end{tabular}

The above table presents the results of the descriptive analysis in the 24 questions. It can be seen that most students do not like using CALL quite often to assist their English learning as the medians of most questions were less than 3, particularly, the use of it out of classes. The only question item students chose to use CALL quite often was Q23, regarding computers-assisted method to learn English songs out of English classes ( $\mathrm{SD}=4)$. Three questions (Q2, Q9, and Q16) need further analysis by utilizing Kruskal-Wallis tests as their median values are 3, which indicated that the participants' views on these questions were divided (Pallant, 2007). The aim of using the Kruskal-Wallis test was to find out the factors that might be influential in regard to these responses. This test was used to determine whether the participants' gender, academic faculties, course, nationality, and places when they finished their secondary education, were associated with their behaviors in relation to using CALL in their English learning.

Analysis of Q2 'How often do you use CALL to learn English vocabularies?'

Kruskal-Wallis tests were performed on Q2 by the four factors: gender, academic faculty, ethnics and urban/rural areas. All of these factors, including gender $\left(X^{2}=0.420, \mathrm{df}=1, \mathrm{p}\right.$-value $\left.=0.517>0.05\right)$, ethnics $\left(X^{2}=1.473, \mathrm{df}=\right.$ 1 , p-value $=0.225>0.05)$, academic faculty $\left(X^{2}=3.515, \mathrm{df}=3, \mathrm{p}\right.$-value $\left.=0.319>0.05\right)$, and urban/rural $\left(X^{2}\right.$ $=0.121, \mathrm{df}=1, \mathrm{p}$-value $=0.728>0.05)$ do not correlate with the participants' responses on this question as their p-values are larger than 0.05(Pallant, 2007).

Analysis of $Q 9$ 'How often do you use CALL method to watch English movies or English TV programs?' 
Similarly to the Q2, after the Kruskal-Wallis tests were performed, the four independent variables were not correlated with the participants' responses on this question. Gender $\left(X^{2}=0.614, \mathrm{df}=1, \mathrm{p}\right.$-value $\left.=0.433>0.05\right)$, ethnics $\left(X^{2}=0.000, \mathrm{df}=1, \mathrm{p}\right.$-value $\left.=0.991>0.05\right)$, academic faculty $\left(X^{2}=7.529, \mathrm{df}=3, \mathrm{p}\right.$-value $\left.=0.057>0.05\right)$, and urban/rural $\left(X^{2}=1.407, \mathrm{df}=1, \mathrm{p}\right.$-value $\left.=0.236>0.05\right)$

Analysis of Q16'How often do you use CALL method to preview and review English texts?'

When Kruskal-Wallis tests were performed on Q16, no correlation was found between students' responses and two factors: ethnics $\left(X^{2}=1.937, \mathrm{df}=1, \mathrm{p}\right.$-value $\left.=0.164>0.05\right)$, and urban/rural $\left(X^{2}=0.499, \mathrm{df}=1, \mathrm{p}\right.$-value $=$ $0.480>0.05)$. However, correlations were found with factors of gender $\left(X^{2}=4.696, \mathrm{df}=1, \mathrm{p}\right.$-value $=0.030<$ $0.05)$, and academic faculty $\left(X^{2}=12.660, \mathrm{df}=3\right.$, p-value $\left.=0.005<0.05\right)$. Details are shown in the following tables:

Table 2. Kruskal-Wallis test on Q16 by gender

\begin{tabular}{llll}
\hline Gender & $\mathbf{N}$ & Mean Rank & Median \\
\hline Male & 163 & 162.26 & 2.000 \\
Female & 184 & 184.40 & 3.000 \\
Total & 347 & & 3.000
\end{tabular}

Chi-Square value $=4.696, \mathrm{df}=1, \mathrm{p}$-value $=0.030<0.05$

The significance level 0.030 shown in the above output suggests a statistical significant difference in the participant behaviors on using CALL as an efficient method to preview and review English texts (Kinnear \& Gray, 2009). An investigation of the mean ranks indicates that the female students (Mean Rank $=184.40$ ) held a more positive view on this question than male students (Mean Rank=162.26). That is, female students like using computers as technology to assist them in previewing and reviewing English learning materials.

Table 3. Kruskal-Wallis test on Q16 by academic faculty

\begin{tabular}{|c|c|c|c|c|}
\hline Academic faculty & & $\mathbf{N}$ & Mean Rank & Median \\
\hline Arts & & 112 & 175.82 & 3.000 \\
\hline Science & & 123 & 189.68 & 3.000 \\
\hline $\begin{array}{l}\text { Technology } \\
\text { Engineering }\end{array}$ & and & 44 & 179.28 & 3.000 \\
\hline Fine Arts and PE & & 68 & 139.21 & 2.000 \\
\hline Total & & 347 & & 3.000 \\
\hline
\end{tabular}

Chi-Square value $=12.660, \mathrm{df}=3, \mathrm{p}$-value $=0.005<0.05$

The result of Kruskal-Wallis on Q16 is presented in Table 3 by four academic faculties. The significance level 0.005 shown in the above output suggests a statistical significant difference in the participant behaviors across different academic areas (Kinnear \& Gray, 2009; Pallant, 2007). An investigation of the mean ranks indicates that the Science Faculties (Mean Rank $=189.68$ ) held the most positive view on this question, with the Fine Arts and PE Faculties (Mean Rank $=139.21$ ) reporting the least. In order to investigate which groups are statistically significantly different from one another, Mann-Whitney $U$ tests were performed between all the groups. The Mann-Whiney test shows that no significant difference was found between Arts and Science ( $U=6326.500, Z=$ -1.141, $\mathrm{p}=0.254>0.05)$, Arts and Technology \&Engineering $(\mathrm{U}=2411.000, \mathrm{Z}=-0.221, \mathrm{p}=0.825>0.05)$, and Science and Technology \&Engineering $(\mathrm{U}=2543.500, \quad \mathrm{Z}=-0.623, \mathrm{p}=0.533>0.05)$. However, statistically significant differences were found in the following groups:

- $\quad$ Arts and Fine Arts \&PE $(U=2989.500, Z=-2.562, P=0.010<0.05)$

- $\quad$ Science Faculty and Fine Arts \& PE $(U=2977.000, Z=-3.477, p=0.001<0.05)$ 
The median values also approve that participants from the Faculty of Fine Arts \& PE (Median=2) hold a more negative views on this question than other faculty participants (Median=3).

\section{Results of Qualitative Data}

Compared with the numerical data in the first phrase, at this stage, textual data was gathered from the participants' responses in the semi-structured interview. Prior to the interview, every participant could obtain an outline of the interview questions and interview process, which could guide participants to answer questions in the formal interview (Neuman, 2011). The 20 participants were from the four academic faculties mentioned above and their background information is summarized in Table 4.

Table 4. Information of interview participants

\begin{tabular}{|c|c|c|}
\hline Academic faculty & Students & Gender \\
\hline 1. Arts & $\begin{array}{l}\text { Student 1-A (Freshman) } \\
\text { Student 2-A (Sophomore) } \\
\text { Student 3-A (Freshman) } \\
\text { Student 4-A (Freshman) }\end{array}$ & $\begin{array}{l}F \\
F \\
F \\
F\end{array}$ \\
\hline 2. $\quad$ Science & $\begin{array}{l}\text { Student 1-S (Senior) } \\
\text { Student 2-S (Junior) } \\
\text { Student 3-S (Senior) } \\
\text { Student 4-S (Freshman) } \\
\text { Student 5-S (Freshman) }\end{array}$ & $\begin{array}{l}\mathrm{F} \\
\mathrm{M} \\
\mathrm{F} \\
\mathrm{M} \\
\mathrm{M}\end{array}$ \\
\hline 3. Technology \& Engineering & $\begin{array}{l}\text { Student 1-TE (Junior) } \\
\text { Student 2-TE (senior) } \\
\text { Student 3-TE (Senior) } \\
\text { Student 4-TE (Freshman) } \\
\text { Student 5-TE (Sophomore) } \\
\text { Student 6-TE (Freshman) } \\
\text { Student 7-TE (Sophomore) }\end{array}$ & $\begin{array}{l}\text { F } \\
F \\
F \\
F \\
M \\
M \\
F\end{array}$ \\
\hline 4. $\quad$ Fine Arts \& PE & $\begin{array}{l}\text { Student 1-FAPE (Freshman) } \\
\text { Student 2-FAPE (Sophomore) } \\
\text { Student 3-FAPE (Senior) } \\
\text { Student 4-FAPE (Freshman) }\end{array}$ & $\begin{array}{l}\mathrm{F} \\
\mathrm{M} \\
\mathrm{F} \\
\mathrm{F}\end{array}$ \\
\hline
\end{tabular}

From Table 4, it can be seen that the number of female students $(\mathrm{N}=14)$ in the interview is over twice as many as male students $(\mathrm{N}=6)$. Interestingly, the number of participants from the Faculty of Technology \& Engineering $(\mathrm{N}=7)$ are the most within the four faculties. These 20 participants ranged from 17 years-old to 24 years old students on campus, including 9 freshmen, 4 sophomores, 2 juniors, and 5 seniors. Some interesting results were found within the textural data, which was grounded from students' responses of the raw data.

After the constant comparisons and relocation, 4 core categories were generated from the participants' views. The details are presented as follows:

- Negative attitudes towards the application of the CALL

- Positive attitudes towards the application of the CALL

- Students' expectations

- Educational system 


\subsection{Negative Attitudes towards the Application of the CALL}

The most significant category emerged from the coding process was "Negative attitudes towards the application of the CALL", which had 113 responses. Within this category, students shared their opinions on this technology used in daily learning and teaching. Most of them hold a negative view on it, such as difficulties of accessing the Internet out of classes, a lack of technological skills, a lack of computer training and workshops, cultural conflicts, work in isolation, limited time with it, cost and effectiveness. One participant told the researcher that she did not like using computers to learn English at all. She thought that there were three main reasons that had influenced her to use computers as a method to assist in language learning. The first one was the cost. Her family was in the mountain areas of China, where the people still lived under the poverty line nowadays. Many of them could not afford children to receive secondary education, let alone to buy a computer for children to learn a foreign language in the university. The only place she used computers was in the library. However, the library lab was not open in holidays and weekends. Therefore, she found it was difficult to study with help of computers. Worse, she found she felt soashamed in front of some students who owned a PC and high technology appliances that she could not live and study with.

\subsection{Positive Attitudes towards the Application of CALL}

However, some students still hold a positive attitude on the wide use of CALL in language learning in the university at present. An example was give below:

I think computers are very good as a supplementary way to help me in English learning, especially, when my English tutors asked for leave or was in holiday. I use it to listen to English news, which I have found it is the most effective method to improve my English and listening. Also, I use my PC to preview and review English texts, which is more applicable and smart for me to take.

\section{Student 5-TE (Sophomore)}

\subsection{Students' Expectations}

Within this category emerged, students hope that they would have had more chances to use computers to assist their English learning when they were in secondary schools. Since only computers were provided in the university at present, they could not adapt to the new teaching and learning environment in a short time. Also, workshops and technological trainings regarding computer skills are a necessary provision every semester. A significant number of students proposed that computers should be accessed at weekends in the university computer labs or in the library otherwise it is difficult for them to study out of English classes.

\subsection{Educational System}

The least responses the researcher got were codes within the "Educational system" category. 31 responses were gathered addressing the problems in the current Educational system, such as teachers taking a dominant role in classes, college exam-orienting in secondary education, and final exams still being important in Chinese universities. A participant shared his opinions with the researcher, saying:

I did not have any access to computers when I was in high schools. What my English teachers did everyday was to force us to finish a load of homework and exam papers. I felt like a child who was spoon-fed by my teachers. In my spare time, I really would like to turn my PC on to listen to English songs, but my parents did not allow me to do it since they thought I would play computer games with it instead of learning English. In a word, an exam-oriented educational system was harmful for the young guys like me.

\section{Student 3-FAPE (Senior)}

\section{Suggestions and Conclusion}

From both the quantitative results and qualitative results, it can be concluded that students in these two universities did not hold a positive attitude on the application of CALL. Also, students' behaviors from the questionnaire indicated that they did not like using the CALL to assist their English learning, particularly, out of English classes. In a Chinese context, teachers are playing a dominant role in the classrooms instead of students. They use textbooks and exam papers as a main learning and teaching tool, which influence students over several decades (Hu, 2002). According to the findings, suggestions are provided as follows:

1. There is a pressing need for students to become familiar with IT as a tool to help their learning process based on Lam's suggestions(2000). Lim (2007) believes that students should be encouraged to construct learning content actively by themselves with the use of IT rather than receiving teachers' instruction all the time. Therefore, universities and schools should encourage students to have more chance to access IT in 
classes and out of classes as Lam (2000) thinks exposure to access more computers is the best solution to solve IT-related problems.

2. Training is also necessary. Although teachers' attitudes were not involved in this research, Warschauer and Healey (1998) believe that if training teachers to use IT efficiently or not is a key element to success in the effective use of CALL. Also, students need training as well. Chapelle and Hegelheimer(2004) argued that users not only need computer competence but also should know how to locate materials appropriately, for example, learning how to use search engines and performing searches.

3. The exam-oriented educational system should be innovated and reformed in the direction of developing and cultivating students' creativity and diversity in language learning. In the near future, high schools students and primary schools kids should be provided with more chances to access computers in mainland China; otherwise, a policy based reform to use CALL in universities would be unlikely to be welcomed by students.

This study is conducted in a Chinese context to explore students' attitudes and behaviors on the application of CALL. It emphasizes the importance of investigating human agency and their attitudes towards to use any IT tools prior to use them widely in the word, especially, the adoption of CALL as a remedial approach tool to assist language learning and teaching in Chinese mainland universities. This paper uses mix methods to collect and analyze data. The results show that majority of university students would like to use CALL under the condition of being provided with efficient guidance at the first place.

\section{References}

Albirini, A. (2006). Teachers' attitudes toward information and communication technologies: The case of Syrian EFL teachers. Computers \& Education, 47, 373-398. http://dx.doi.org/10.1016/j.compedu.2004.10.013

Bazeley, P. (2010). Computer assisted integration of mixed methods data sources and analyses. In A. Tashakkori, \& C. Teddlie (Eds.), Handbook of mixed methods research for the social and behavioral sciences (2nd ed., pp. 431-467). Thousand Oaks, CA: Sage.

Braul, B. (2006). ESL teacher perceptions and attitudes toward using computer assisted language learning: Recommendations for effective CALL practice (Master's thesis, University of Alberta). Retrieved March 2, 2013.

Brown, J. D. (2001). Using surveys in language programs. Cambridge: Cambridge University Press.

Chapelle, C. A., \& Hegelheimer, V. (2004). The language teacher in the 21 st century. In S. Fotos, \& C. M. Browne (Eds.), New perspectives on CALL for second language classrooms (pp. 299-316). New Jersey: Lawrence Erlbaum Associates.

Cox, M., Preston, C., \& Cox, C. (1999). What factors support or prevent teachers from using ICT in the primary classroom. Paper presented at the British Educational Research Association Annual Conference, Brighton.

Creswell, J. W. (2009). Research design: Qualitative, quantitative, and mixed methods approaches (3rd ed.). Los Angeles: Sage.

Cubillos, J. H. (1998). Technology: A step forward in the teaching of foreign languages. In J. Harper, M. Lively, \& M. Williams (Eds.), The coming age of the profession (pp. 37-52). Boston: Heinle \& Heinle.

Davis, F. D. (1989). Perceived usefulness, perceived ease of use, and user acceptance of information technology. MIS Quarterly, 13, 319-340. http://dx.doi.org/10.2307/249008

Fan, S. (2011). Significance of the Web as a Learning Resource in an Australian University Context (PhD thesis). University of Tasmania, Launceston.

Fisher, E. (1993). Access tolearning: Problems and policies. In P. Scrimshaw (Ed.), Language, classrooms and computers (pp. 75-90). London: Routledge.

Furstenberg, G. (1997). Teaching with technology: What is at stake? ADFL Bulletin, 28, 21-25. http://dx.doi.org/10.1632/adfl.28.3.21

Hu, G. (2002). Potential cultural resistance to pedagogical imports: The case of communicative language teaching in China. Language, Culture and Curriculum, 15(2), 93-105. http://dx.doi.org/10.1080/07908310208666636

Johnson, R. B., \& Onwuegbuzie, A. J. (2004). Mixed method research: A research paradigm whose time has come. Education Research, 33(7), 14-26. http://dx.doi.org/10.3102/0013189X033007014

Johnson, R. B., \& Turner, L. A. (2002). Data collection strategies in mixed methods research. In A. Tashakkori, 
\& C. Teddlie (Eds.), Handbook of mixed methods in social and behavioral research (pp. 297-319). Thousand Oaks, CA: Sage.

Jung, H. J. (2005). Advantages and disadvantages from opportunities in CALL classroom environments. The Reading Matrix, 5(1), 57-72.

Kern, R. (2006). Respectives on technology in learning and teaching languages. TESOL Quarterly, 40(1), 183-210. http://dx.doi.org/10.2307/40264516

Kessler, G. (2007). Formal and informal CALL preparation and teacher attitude toward technology. Computer Assisted Language Learning, 20, 173-188. http://dx.doi.org/10.1080/09588220701331394

Kinnear, P. R., \& Gray, C. D. (2009). SPSS 16 made simple. East Sussex: Psychology Press.

Lam, Y. (2000). Technophilia or technophobia? a preliminary look at why second language teachers do or do not use technology in their classrooms. Canadian Modern Language Review, 56, 389-420. http://dx.doi.org/10.3138/cmlr.56.3.389

Liaw, S. S. (2002). An Internet survey for perceptions of computers and the World Wide Web: Relationship, prediction, and difference. Computers in Human Behavior, 18, 17-35. http://dx.doi.org/10.1016/S0747-5632(01)00032-2

Likert, R. (1932). A technique for the measurement of attitudes. New York: Archives of psychology.

Lim, C. P. (2007). Effective integration of ICT in Singpore schools: Pedagogical and policy implications. Educational Technology Research and Development, 55, 83-116. http://dx.doi.org/10.1007/s11423-006-9025-2

Ma, W., Andersson, R., \& Streith, K. O. (2005). Examining user acceptance of computer technology: An empirical study of student teachers. Journal of Computer Assisted Learning, 21, 387-395. http://dx.doi.org/10.1111/j.1365-2729.2005.00145.x

Markee, N. (1997). Managing curricular innovation. Cambridge: Cambridge University Press.

Neuman, W. L. (2011). Social research methods: Qualitative and quantitative approaches (7th ed.). Boston, MA: Allyn and Bacon.

Pallant, J. (2007). SPSS survial manual (3rd ed.). Crows Nest NSW: Allen \& Unwin.

Rogers, E. M. (1983). Diffusion of innovations. New York: The Free Press.

Seyed, A. F. J., \& Farimah, S. (2013). Exploring the human element of computer-assisted language learning: An Iranian context. Computer Assisted Language Learning, 26(2), 158-176. http://dx.doi.org/10.1080/09588221.2011.643411

Stockwell, G., \& Harrington, M. (2003). The incidental development of L2 proficiency in NS-NNS email interaction. CALICO Journal, 20(2), 337-360.

Tashakkori, A., \& Teddlie, C. (1998). Mixed methodology: Combining qualitative and quantitative approaches. Thousand Oaks, CA: Sage.

Wang, Y. P. (2004). Distance language learning: Interactivity and fourth generation Internet-based videoconferencing. CALICO Journal, 21(2), 373-395.

Warschauer, M. (2002). A development perspective on technology in language education. TESOL Quarterly, 36, 453-475. http://dx.doi.org/10.2307/3588421

Warschauer, M., \& Healey, D. (1998). Computers and language learning: An overview. Language Teaching, 31, 57-71. http://dx.doi.org/10.1017/S0261444800012970

Yang, F. Y., \& Tsai, C. C. (2008). Investigaing university student preferences and beliefs about learning in the


http://dx.doi.org/10.1016/j.compedu.2006.12.009

Yang, P. J. (1998). Networked multimedia and foreign language education. CALICO Journal, 15(1-3), 75-88.

Yang, S. C., \& Chen, Y. J. (2007). Technology-enhanced language learning: A case study. Comparison in Human Behavior, 23, 860-879. http://dx.doi.org/10.1016/j.chb.2006.02.015

Yuen, A., \& Ma, W. (2002). Gender differences in teacher computer acceptance. Journal of technology and Teacher Education, 10, 365-382. 